Article

\title{
An Examination of the Interaction of Democratic Ideals with Journalism Training Programmes in the Global South: The Case of Cambodia
}

\author{
Fergal Quinn \\ School of English, Irish, and Communication, University of Limerick, Limerick V94 XT66, Ireland; \\ fergal.quinn@ul.ie
}

Received: 23 October 2020; Accepted: 13 December 2020; Published: 18 December 2020

\begin{abstract}
The presumption that a liberal media landscape and associated press culture strengthens good governance and human development has approached orthodoxy in the western world. Consistent with this, journalism training has been a central component of media aid strategies in the Global South. This research examines how normative assumptions about journalism roles can interact with ideas about democracy in a training environment and the possible implications of this. It explores parallels between programme elements relating to democracy facilitation and particular role conceptualisations of journalists trained by these programmes, with a specific interest in how this process is borne out in countries where democratisation processes are ongoing. A qualitative-based methodology, using journalism training in Cambodia as a case study, finds some correlations between democracy-related emphases at training level and specific normative orientations among working journalists who participated in these programmes. However, we find that these democratic norm-related orientations of practitioners contain subtle, but key differentiations from those advocated by programme facilitators. A vocational, advocacy-oriented approach to journalism programmes may have contributed to this outcome in a Cambodian context.
\end{abstract}

Keywords: journalism education; journalism norms; democracy; qualitative research; case-study

\section{Introduction}

It is generally accepted that values such as accuracy, truthfulness and fairness are integral to what journalism as a practice is based upon. However, the question of which principles are core, irreducible values that must be adhered to, and which ones reside more in the realm of professional ideals, or aspirations remains contested (See for example the debate around the practical applicability of 'objectivity'). Whatever position one takes, journalistic values and ideals are a key component of what journalism training programmes focus on.

This study is interested in one such journalistic normative ideal-that of democracy. The histories of journalism and democracy have long been interlinked, with the press seen as essential in informing citizens about the world around them, scrutinising how power is exercised and facilitating informed voting choices (McNair 2009; Josephi 2013) and in so doing contributing to political, economic, social and cultural development" (UNESCO 2013). This encompasses facilitative, monitorial and confirming functions (these are teased out in more detail later). While it is broadly accepted that a free press is an intrinsic component of established democracies in the west (Nielsen (2017) describes this as a "central normative anchoring point" (p. 1252) for much journalism scholarship), the precise nature of the relationship and its implications for non western environments is contested.

The key question this paper interrogates is: how does the democratic norm manifest itself in journalism training that is facilitated as part of an externally supported democratisation process in the 
Global South and what are the implications of this? Due to the fact that the case study being used here, journalism programmes in Cambodia in the mid 1990s onwards, was supported by organisations focused on democracy-building activities, it takes as a given that this specific variation of the norm-that journalism is a facet of what brings democracy intro being-is core to how the relationship between journalism and democracy was conceptualised in these instances. Before examining the experiences of key informants from the period being examined, I first establish a broad theoretical framework from which to make sense of some of the 'presumptions' and 'givens' touched on above, as a means of better understanding how the democratic norm is assumed to interact with the democratisation process.

I begin with an overview of some of the primary characteristics that make Cambodia a pertinent case study here. This sets up a broader discussion on the interaction of journalism norms and ideals with cultural variations, particularly in the Global South, before placing this within the evolution of the relationship between democracy and journalism, specifically in terms of the democratisation process. From here, I consider different models and approaches to journalism training as part of foreign aid programmes. An overview of the methodological approach outlines a rationale for gathering and analyzing interview-based data, gathered between 2011 and 2013, followed by a discussion section which considers key emergent findings.

\section{Cambodia and Journalism Training}

Cambodia, between the years of 1993 and 2013 is a particularly good place in which to situate a study of the interaction of the democracy norm and journalism training for a number of reasons. Firstly, it offers a vivid example of a place and a period in which international best practice in terms of journalism education was applied for a sufficient period of time that such an assessment can be useful. After a combination of civil war, the genocidal Khmer Rouge regime and the Vietnamese occupation devastated Cambodia economically and culturally, the rebuilding process undertaken by the United Nations Transitional Authority in Cambodia (UNTAC) intervention in the 1990s intended to encourage the development of a free press, which it was hoped would support and help consolidate a genuinely liberal democratic government structure (UNTAC 1991). Supplementing new media-friendly legislation and a more amenable economic environment that followed this rebuilding process, numerous international and western aid organisations became involved in journalism training programmes (Clarke 1995). Thus, the journalism programmes carried out in Cambodia during this time period were very explicitly positioned as part of democratisation efforts.

Secondly, efforts at training journalists in the 1990s in Cambodia were attempted based on what might be regarded as a 'clean slate' (this term is used in a very qualified fashion), meaning data can potentially be mined which is less tainted by the kinds of difficult-to-quantify external variants and factors that would be present in a more normalised case. This is due to the fact that what little experience Cambodia had of a journalistic culture historically was wiped out under the Khmer Rouge regime and the period of unrest that followed. Thus, normative conceptualisations of journalists can more readily be linked to the specific programmes being examined here than might otherwise have been the case.

A third factor which makes Cambodia an interesting case study is that there is ample evidence on the ground that a democratic political outcome has not resulted there to the extent that proponents of journalism programmes there hoped. Cambodia was, at the time that interviews were carried out, officially a multi-party democracy under a constitutional monarchy, even as the reality more closely resembled an authoritarian state (Bumille 2012). However, the democratic and media situation has declined precipitously in Cambodia since, with the 2018 parliamentary election, in which Prime Minister Hun Sen's ruling CPP took nearly all available seats following a major crackdown on the media and opposition (Lamb 2018) the latest nadir. Almost every reputable analysis of the country (Reporters San Frontiers 2019; Freedom House 2020) have concurred that the current Cambodian media climate is not free. Thus, this study offers a snapshot of a scenario in which the democratisation process was on what can now be confirmed as something of a downward spiral. Cambodia then, offers a 
useful case study, but what are the other aspects that feed into the relationship between journalism and democratisation and what are the contested areas that might offer a framework with which to understand the Cambodian experience in this regard.

The choice to situate this study in Cambodia is also opportunistic. Between 2006 and 2008, I worked as a journalist with the Phnom Penh-based Cambodia Daily ${ }^{1}$ newspaper. The Daily was set up primarily as a means of local journalists being trained in 'best practice' by western trained reporters who work alongside them and represented an unusual experiment in combining a profit making newspaper with a NGO-style media training ethos. The initial hypothesis that inspired this research emanated from observations I made while working with the Daily.

\section{Cultural Variations of Journalism Ideals}

Any discussion about journalism and journalism training in Global South environments such as Cambodia must acknowledge numerous difficulties experienced by journalists as learned or assumed ideals run into locally specific obstacles. ${ }^{2}$ These are socio- and political-economic in nature, for example the structural and institutional difficulties faced by citizen journalists in the Dominican Republic (Prado 2017) and elsewhere (Beiser 2018), the increasing precarity of Nigerian journalists' working conditions (Matthews and Onyemaobi 2020), newsroom socialisation which has been linked to disinterest in detached, adversarial journalism highlighted across several Global South countries by Kalyango et al. (2017). Other factors which tend to stymie journalism can be more cultural in origin, for example the rooting of norms and value systems central to journalism in western concepts and philosophical foundations (Christians 2009; Plaisance et al. 2012). The blanket application of 'absolutist' journalistic ethical norms in countries which are culturally dissimilar has been linked to elitism (Banda 2007), unexpected or poorly understood interpretations of these norms (Tsukamoto 2006; Ward 2008), lack of applicability in repressive environments (Cortadi et al. 1992) and an ignorance of pre-existing ethical frameworks (Wasserman and De Beer 2004; Hamada 2016).

Discourses around alternative, and more inclusive frameworks for journalism ideals have emphasised the socially constructed and negotiated aspect (Ward 2008), particularly during times of social transformation (Hanitzsch et al. 2011; Lo et al. 2005). This has led to pressure to enlarge the conceptual base of journalism ethics and the increased integration of "indigenous epistemologies" within global media ethics (Rao and Wasserman 2007, p. 30). Lugo-Ocando (2018) finds a positive overall trends in this regard with the broad convergence in normative claims and aspirations around journalism values and ethics all over the world. However, the likes of Meyers (2016) warns against replacing the extremes of reason dependent absolutism with those of cultural relativism.

\section{Democracy and Journalism}

The discourse around the westcentric nature and inappropriateness of aspects of general journalism ideals or practice in non-western environments are also prominent in critiques of the assumed relationship between journalism and democracy (Nielsen 2017; Josephi 2017; Hanitzsch and Vos 2018; Entman 2010; Lugo-Ocando 2018). Vigorous and influential critiques by the likes of Appadurai (1996) argued that while symbols associated with liberal democracy—for example freedom, rights, welfare, sovereignty, elections, representation, environmental protection, cosmopolitanism and democracy-are projected from the western world via a global media, the reality has been "the deepening of the ideals of freedom and human dignity only for an elite, while increasing the misery of the rest" (Harvey 2005, p. 37). Instead of truly advancing the core principles of liberal democracy,

The newspaper was shuttered by the Cambodian government in 2017.

2 Our usage of the term Global South' here is primarily the conventional nation state definition (used by the World Bank and others) to describe low to middle income countries), but can also be broadly applied to what Mahler (2018) describes a more de-territorialised political economy definition of the term encompassing groupings of people and countries whose social agency is negatively impacted by globalisation. 
Herman and McChesney (1997) argued that this mediation instead acts as the new missionary for global corporate capitalism. The counter-reaction to such mediated symbols has been linked to revolutionary responses, for example the violent destruction of the symbols of capitalism by anti-globalisation movements or via an affirmation of cultural specificity, evidenced through the discourse of 'Asian Values' in society generally (Pye and Pye 1985) and then to journalism particularly (Dissanayake 1988).

This research is specifically interested in the perceived role of journalism in a media aid environment, and by extension linkages between specific journalism roles and the process of 'democratisation' in Global South countries. The literature in this regard has tended to coalesce around the importance and influence of the monitorial, facilitative and collaborative roles of the press. The monitorial role, for example, is seen as particularly useful in that it serves citizens who actively seek information in order to participate in the democratic process (Schudson 1998; Hackett 2017). Critics (Cammaerts et al. 2017; Donohue et al. 1995), however, have questioned the press' ability serves this type of function, given its lack of independence from broader political economic forces. A facilitative-oriented press is thought to strengthen and broaden civil society by bringing social, administrative and financial issues from the political to the public realm, providing the information that moves a public to meaningful judgement and action (Denzin 1997). During a democratisation process, Bennett (1998) calls this a confirming role. However, difficulties in achieving this have been observed in post-authoritarian environments in particular (El Issawi and Cammaerts 2016). A 'collaborative' oriented press, which actively supports a particular agenda for what is perceived to be the greater good, is perhaps the most controversial of these perceived democratisation-supporting functions. It is linked strongly to developmental journalism (Christians 2009), a type of journalism which works alongside the state to pursue the benefits of modernisation for the nation as a whole. However, there are serious questions about the autonomy of this type of press and its ability to critique the power it has allied itself with (Banda 2007).

Berger (2000) outlining of the way variants of the democratic norm influence press' interaction with democratisation further distils our understanding of the relationship. His liberal variant of the norm sees journalism as an active, autonomous force safeguarding citizens' rights, with a strong 'watchdog' orientation. The social democratic variant stresses the press' guiding, and educational role in a way that is traditionally linked to public service broadcasting. The neoliberal variant, on the other hand, is more commercially oriented, linking journalism's contribution to democracy to reflecting pluralism and diversity in debates, with the press acting as neutral referees in the contest of political forces in the service of a public or 'media consumers'. A sense of what variant (if any) predominated in a Cambodian context might shed light on some of the specific ways that certain types of training environments interact with this process.

\section{Journalism Training in the Developing World}

Having established the relationship between differing journalistic roles emphases and how the democratic norm is conceptualised, another key variable for this study is the type of training experienced by practitioners. The discourse around journalism training implementation has tended to centre around implications of vocational (short-term, practical and skills-based) versus educational (more theoretical, institutional and long-term) approaches in the sector. While there is a growing consensus that a mixture of both approaches is best (Datta-Ray 2006; Murthy 2010; Quinn 2018), the proportion of each required remains contentious (Gardeström 2017). 
The traditional dominance of a vocational approach to training in the West ${ }^{3}$ (Anderson 2014) has meant that journalism programmes supported by aid emanating from these countries also tended to adhere to this model (Barrera 2012). This, combined with a dominance of western-oriented learning materials (Quinn 2018) and a general shortfall of research into non-western journalism practice (Dube 2016) has resulted in programmes in non-western environments which tend to emphasise, whether overtly or implicitly, the "self-evident" superiority of Anglo/US journalistic systems (Papoutsaki 2007).

The democratic norm is a central tenet of the type of Enlightenment-influenced universalism applied to curriculum-building by UNESCO (Josephi 2010; Deuze 2005), the body that most influences journalism programmes in the developing world. UNESCO (2013) report on the implementation of journalism curricula, for example, states that the effort derives from a "conviction that professional journalistic standards are essential to a media system that can foster democracy, dialogue and development" (UNESCO 2013, p. 5). ${ }^{4}$ Such assumptions have been found to be problematic in an educational context, however. For example, Josephi (2005) argues that journalism's strong association with democracy has made the practice seem more the prerogative of western nations, as many countries do not seem to provide the democratic basis which seems necessary for journalism. For Foley (2010, pp. 65-66), there is a very real danger that journalism training in post-socialist countries can end up simply replacing one ideologically-oriented position for another. This study wished to avoid the "needlessly oppositional" (Ward 2008) arguments over 'universalisable' versus 'culturally specific' frameworks for journalism values. Instead, the priority here is to begin to address the empirical gap about longer term outcomes of specific approaches to journalism training in democratisation projects.

\section{Methodological Approach and Overview of Data}

This study examines how the democratic norm of journalism manifested itself in journalism programmes carried out as part of broader democratisation efforts and considers some possible implications of this. A mixed methodology, incorporating a case study and qualitative interview-based approach was used to answer two key questions: How did the democratic norm influence programme facilitators' approach to journalism training? How did ideas about the democratic norm manifest themselves within participants' role conceptualisations and their approach to journalism practice?

Interviews were carried out with a mix of those involved in facilitating training efforts in Cambodia and those who became practitioners after having participated in these courses. A qualitative semi-structured interview-based approach was chosen as the best means of obtaining responses that reveal latent content which subjects may not fully understand or articulate themselves (Jallov 2005). Judgement (Hoepfl 1997), convenience and snowball sampling (Biernacki and Waldorf 1981) were used to select 54 key stakeholders in this process. Following the selection of interviewees, contact

3 It should be noted here that the vocational approach to journalism training in the west has evolved significantly in recent years towards a more education-oriented (longer-term, theoretical and institution-based) approach (Gardeström 2017). However, the historical dominance, as well as poor educational infrastructure and other practical obstacles, has meant that journalism programs in developing countries supported by Western aid have retained a vocational, practice-oriented and short-term, primarily aimed at building a broad level of basic capacity in the sector (Foley 2006). In Cambodia, as in other countries, this approach did evolve (further discussion on the more educationally oriented approach taken by the Konrad Adenauer Foundation from 2005 onwards is discussed later in this paper). However, the primary focus here is on the effect of that 'early-stage' approach to training (similar approaches to which are still being replicated elsewhere) and how this interacted with the understanding of the democratic norm. It must also be noted here that academically oriented approaches to journalism education are not without their problems, for example Vasilendiuc and Sutu (2020) highlighting of weaker adherence to professional values shown by student journalists who reiterated an academically induced picture of the profession. The position of UNESCO in the historical debate on approaches to journalism training and media support in non-western
environments is multi-faceted and more complex than this paper has the space to fully explore. To briefly summarise, UNESCO became a centre of activity for the New World Information and Communication Order (NWICO) debate during the 1970s and 80s, which critiqued what it identified as 'Imperialistic' tendencies inherent in approaches to encouraging media development in the non-western world. This critique and its proponents were sidelined to a degree by geopolitical manoeuvrings in the Cold War, but remains influential today in UNESCO and elsewhere. However, critics have claimed that any changes to the UNESCO approach at a local level have remained somewhat cosmetic, a critique which UNESCO itself acknowledges in its 2013 report on the adaptation of their model curricula. 
was made via email initially and interviews were carried out between 2011 and 2013. Interviews lasted between one and two hours and were carried out at a location of the interviewee's choosing. The majority of interviews were carried out in person with an interpreter present where the informant's native language was Khmer. A small number of interviews were carried out over the phone or via videocall (for example in instances where programme facilitators or trainers were no longer residing in Cambodia), and some follow-up calls were made in some instances to clarify or follow up on some elements of information or topics.

A first category of 25 interviews (Described here as 'Facilitators') examined influences, both explicit and implicit, when constructing and implementing key programme objectives (See Table 1). 19 organisations were involved in implementing journalism training in Cambodia to a sustained level between 1993 and 2011, including eight primary 'on-the-ground' facilitators and 11 prominent outside facilitators/donors. During the period examined, an early proliferation of journalism programmes focusing on basic skills began to give way in the early 2000s to a more specialised training in particular on 'key' topics, for example in economics or health communication. There was also a separate push from 2005 onwards, primarily through the activities of the Konrad Adenauer Foundation in partnership with the Royal University of Phnom Penh, toward a more academically oriented approach. ${ }^{5}$

Table 1. Facilitators.

\begin{tabular}{cc}
\hline Local Cambodian Trainer (TL) & 8 \\
\hline International trainer (TI) & 8 \\
\hline Donor (DR) & 6 \\
\hline Expert Commentator (EC) & 3 \\
\hline TOTAL & $\mathbf{2 5}$ \\
\hline
\end{tabular}

A second phase of 29 interviews ('Participants') focused on the perception of participants who are now practicing journalists, about what they regarded as their most important ideals of journalism and how these influenced their work practices (See Table 2). These were divided into journalists working at the time for locally-funded Khmer language media and those working for non-Cambodian 'international' media, (funded internationally) for a domestic audience.

Table 2. Participants.

\begin{tabular}{cc}
\hline Journalists working in local Khmer language media (JL) & 18 \\
\hline Journalists working in International English language media (JI) & 11 \\
\hline TOTAL & $\mathbf{2 9}$ \\
\hline
\end{tabular}

Other key breakdowns of participants are included below. For example, Figure 1 shows that the range of interviewees in both subcategories are predominantly male, which is representative of the current gender breakdown among journalists.s

A larger proportion of the interviewees in the local journalism category tend to be older overall, with more of those interviewed among the international press aged between 20 and 30 years old (See Figure 2).

5 While the more academically oriented approach taken by the Department of Media and Communication in the RUPP may impact on the Cambodian press sector in the future, too few graduates had emerged at the time of this study to significantly impact on the overall press culture.

6 Expert Commentators' are defined as interviewees with a special degree of knowledge on the subject, but who did not fit into any of the other categories. 

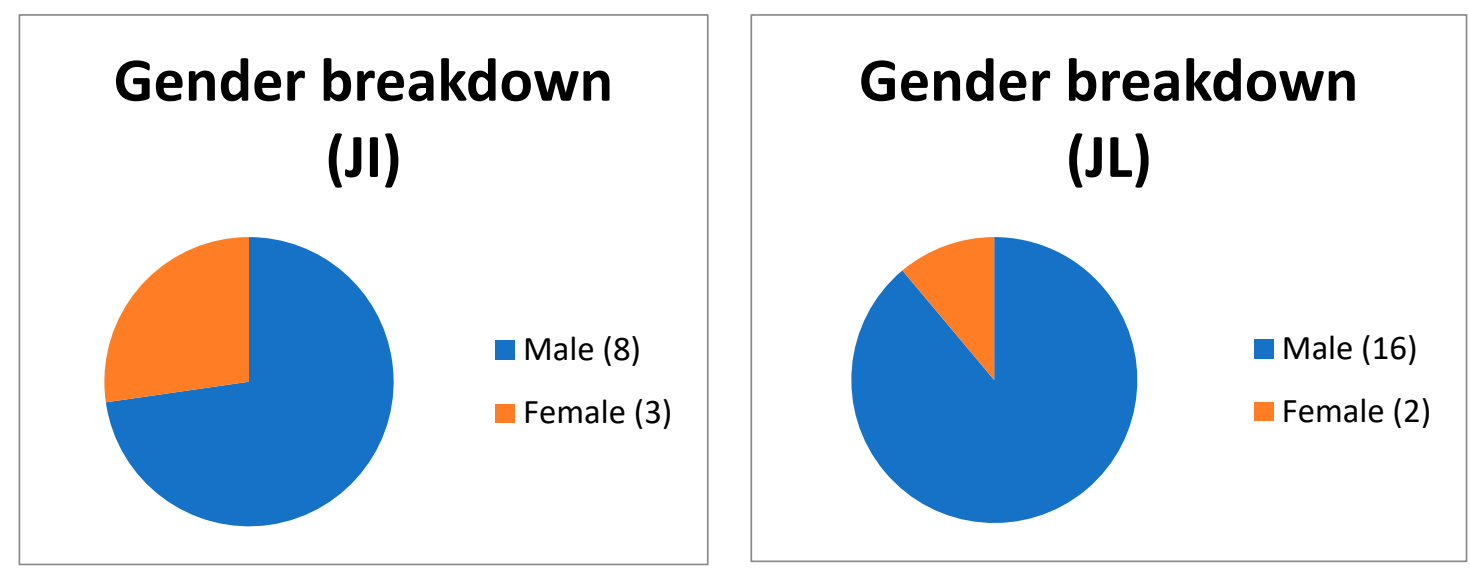

Figure 1. Gender breakdown of Category 2 interviewees.
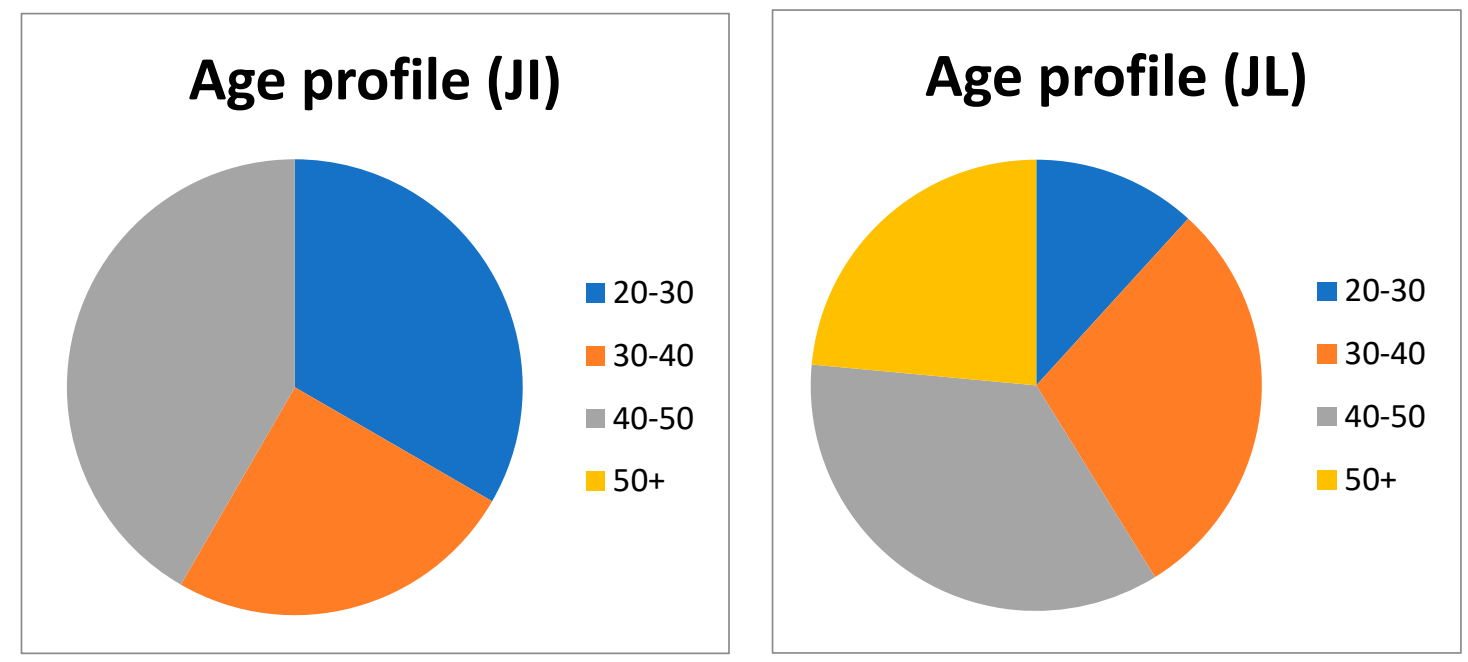

Figure 2. Age breakdown among Category 2 interviewees.

The majority of those interviewed among journalists who were relatively experienced (over 10 years). This was not a deliberate strategy, but may have reflected a sense that those who were willing to talk, in particular in the local press, were those who were longer in their jobs and were subsequently more secure in their positions. Figure 3 gives a breakdown of levels of experience among these interviewees.
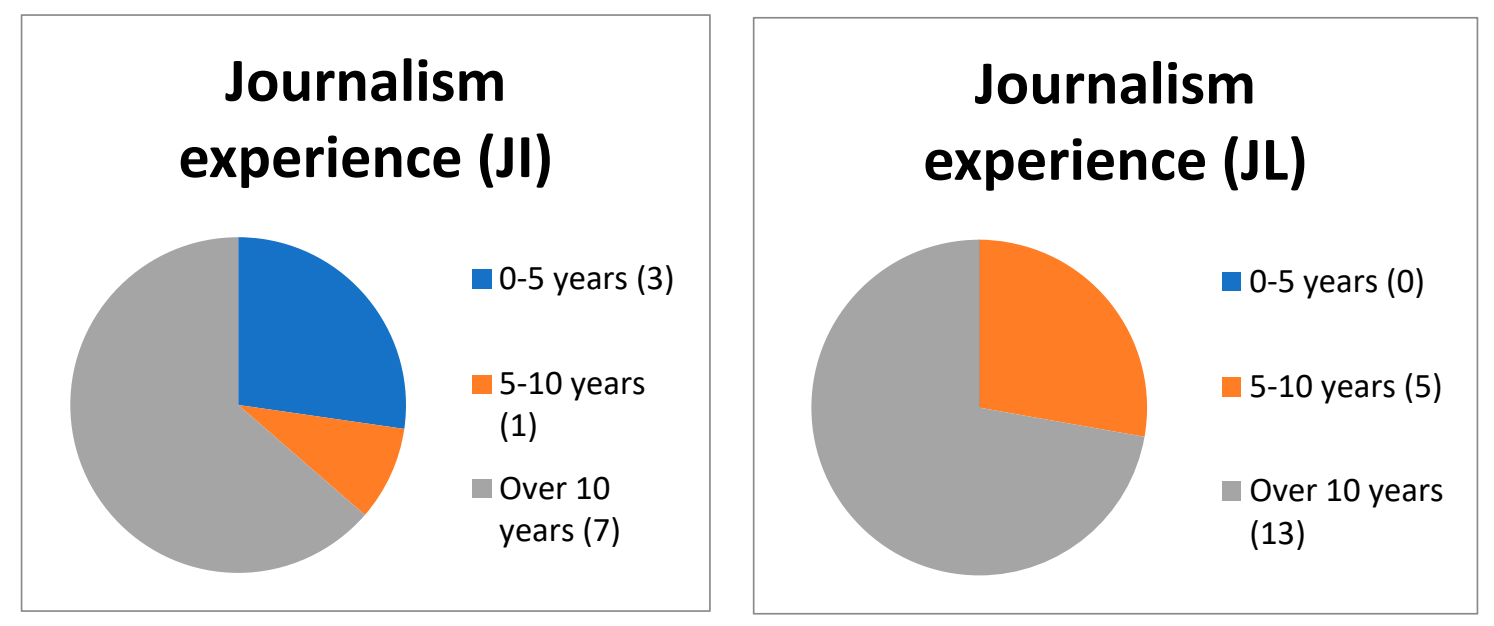

Figure 3. Levels of experience among Category 2 interviewees. 
Interview sheets were based on questions arising from the main research questions. 'Facilitators', for example were asked about programme funding, curriculum formulation, their perception of key journalism roles and values and primary programme objectives. Questions for 'Participants' centred mainly around what they believed to be the most important journalism roles and values. A thematic analysis, which identifies, analyses and reports dominant patterns (themes) within data (Braun and Clarke 2006) was used to make sense of the ideas which emerged from the interviews. By identifying and interpreting recurring thoughts, experiences, feeling and meanings, thematic analyses offer a way to understand training programme facilitators' and journalists' perceptions of normative ideals of the profession and how they connect to programmes that are often not explicitly acknowledged by subjects. I took a deductive approach to this thematic analysis, using existing theory and framing schema to analyse and search for meaning in the data. This approach was used due to it being more detailed and having more of a focus on the relevant aspects of the data (Braun and Clarke 2006). In keeping with a deductive approach, themes were sought from the interview data which are relevant to the ideas related to democracy related normative ideals outlined in the literature review. A theme in this context, as described by Braun and Clarke (2006), captures something important about the data in relation to the research question, and represents some level of patterned response or meaning within the data set. Themes and their meanings are outlined in Table 3.

Table 3. describes codes or subthemes which were identified in the initial phase of analysis. ${ }^{7}$

\begin{tabular}{|c|c|}
\hline Subtheme & Meaning \\
\hline Inform & Giving the public key information they need to make better choices \\
\hline $\begin{array}{l}\text { Affect change } \\
\text { (general) }\end{array}$ & $\begin{array}{l}\text { This means a core function of journalism is to affect change in a broad, } \\
\text { non specific sense }\end{array}$ \\
\hline Watchdog & $\begin{array}{l}\text { This refers to a monitorial role, where the press promotes government transparency } \\
\text { and accountability via public scrutiny of decision-makers }\end{array}$ \\
\hline Improve democracy & $\begin{array}{l}\text { Emphasis here is that function of press is to improve the level of democracy } \\
\text { in Cambodia }\end{array}$ \\
\hline Improve society & Sees journalism as something which improves society \\
\hline $\begin{array}{l}\text { Improve the } \\
\text { government }\end{array}$ & $\begin{array}{l}\text { See journalism as providing information that helps to improve general levels } \\
\text { of governance }\end{array}$ \\
\hline $\begin{array}{l}\text { Exert political } \\
\text { influence }\end{array}$ & This categorisation sees journalism as something which is explicitly political \\
\hline $\begin{array}{l}\text { Encourage free } \\
\text { market }\end{array}$ & $\begin{array}{l}\text { The emphasis here is on journalism as something that helps encourage business } \\
\text { or trade }\end{array}$ \\
\hline $\begin{array}{l}\text { Encourage } \\
\text { development }\end{array}$ & $\begin{array}{l}\text { This sees journalism as having a role in infrastructural and general development of } \\
\text { the country as a means of making the country stronger for all }\end{array}$ \\
\hline $\begin{array}{l}\text { Improve popular } \\
\text { participation }\end{array}$ & $\begin{array}{l}\text { A broader conceptualisation of 'improving democracy', this description placed } \\
\text { journalism explicitly as something which encouraged popular participation in society }\end{array}$ \\
\hline Advocate & In this instance meaning function of representing and promoting particular causes \\
\hline Educate & Journalism described as having key educational function \\
\hline Bridge & Meaning the press facilitates dialogue between the Government and the public \\
\hline $\begin{array}{l}\text { Improve human } \\
\text { rights }\end{array}$ & This sees journalism as something that encourages better adherence to human rights. \\
\hline Attack government & $\begin{array}{l}\text { Informants here describe journalism as having a specific function to be critical, } \\
\text { or attack the government }\end{array}$ \\
\hline
\end{tabular}

Identified themes relating to the research questions are accompanied below by a narrative incorporating observations from relevant categories of interviewees. Interviewees are assigned codes to preserve anonymity, which was deemed necessary given the sensitivity of the political situation in Cambodia and in keeping with the wishes of participants.

7 Where there is overlap between two concepts in responses by informants, both codes were counted separately. 


\section{Finding and Emergent Themes}

Findings are presented here as frequency tables outlining how often particular categories of responses, or codes, arose in interviews numerically and in percentage terms for different categories of respondents. Frequency tables offer a useful foundation from which to pick out dominant tendencies or patterns in the data. These form the basis for the themes, which are described in the thematic analysis.

\subsection{Programme Facilitators' Perceptions of Journalism Functions}

Responses in this section relate to what a total of 25 Category 1 interviewees, including trainers, donors and observers see as the main functions and needs in terms of skills and ethics of journalism and how these were emphasised within the programmes. Responses were given to questions asked via semi-structured interviews sample questions include: Describe your curriculum? What topics are covered? What role should be played by journalists in Cambodia? What are the most important values journalists should have and where do they come from? Table 4 gives an overview of the breakdown here.

Table 4. Trainers/donors' conceptualisations of key journalism functions.

\begin{tabular}{|c|c|c|c|c|c|}
\hline & $\begin{array}{l}\text { TI } \\
8^{8}\end{array}$ & $\begin{array}{c}\text { TL } \\
8\end{array}$ & $\begin{array}{c}\text { DR } \\
6\end{array}$ & $\begin{array}{c}\text { EC } \\
3\end{array}$ & $\begin{array}{c}\text { Overall } \\
25\end{array}$ \\
\hline Inform & $\begin{array}{c}5 \\
(62 \%)\end{array}$ & $\begin{array}{c}5 \\
(62 \%)\end{array}$ & $\begin{array}{c}4 \\
(67 \%)\end{array}$ & $\begin{array}{c}2 \\
(67 \%)\end{array}$ & $\begin{array}{c}16 \\
(60 \%)^{9}\end{array}$ \\
\hline Improve democracy & $\begin{array}{c}4 \\
(50 \%)\end{array}$ & $\begin{array}{c}3 \\
(38 \%)\end{array}$ & $\begin{array}{c}5 \\
(83 \%)\end{array}$ & $\begin{array}{c}2 \\
(67 \%)\end{array}$ & $\begin{array}{c}14 \\
(56 \%)\end{array}$ \\
\hline Watchdog & $\begin{array}{c}3 \\
(38 \%)\end{array}$ & $\begin{array}{c}3 \\
(38 \%)\end{array}$ & $\begin{array}{c}3 \\
(50 \%)\end{array}$ & $\begin{array}{c}0 \\
(0 \%)\end{array}$ & $\begin{array}{c}9 \\
(36 \%)\end{array}$ \\
\hline Affect change (general) & $\begin{array}{c}1 \\
(13 \%)\end{array}$ & $\begin{array}{c}5 \\
(62 \%)\end{array}$ & $\begin{array}{c}2 \\
(33 \%)\end{array}$ & $\begin{array}{c}0 \\
(0 \%)\end{array}$ & $\begin{array}{c}8 \\
(32 \%)\end{array}$ \\
\hline Improve Society & $\begin{array}{c}2 \\
(25 \%)\end{array}$ & $\begin{array}{c}4 \\
(50 \%)\end{array}$ & $\begin{array}{c}2 \\
(33 \%)\end{array}$ & $\begin{array}{c}0 \\
(0 \%)\end{array}$ & $\begin{array}{c}8 \\
(32 \%)\end{array}$ \\
\hline Improve human rights & $\begin{array}{c}2 \\
(25 \%)\end{array}$ & $\begin{array}{c}2 \\
(25 \%)\end{array}$ & $\begin{array}{c}4 \\
(67 \%)\end{array}$ & $\begin{array}{c}0 \\
(0 \%)\end{array}$ & $\begin{array}{c}8 \\
(32 \%)\end{array}$ \\
\hline Improve the government & $\begin{array}{c}1 \\
(13 \%)\end{array}$ & $\begin{array}{c}3 \\
(38 \%)\end{array}$ & $\begin{array}{c}3 \\
(50 \%)\end{array}$ & $\begin{array}{c}0 \\
(0 \%)\end{array}$ & $\begin{array}{c}7 \\
(28 \%)\end{array}$ \\
\hline Exert political influence & $\begin{array}{c}1 \\
(13 \%)\end{array}$ & $\begin{array}{c}4 \\
(50 \%)\end{array}$ & $\begin{array}{c}0 \\
(0 \%)\end{array}$ & $\begin{array}{c}0 \\
(0 \%)\end{array}$ & $\begin{array}{c}5 \\
(20 \%)\end{array}$ \\
\hline Encourage free market & $\begin{array}{c}1 \\
(13 \%)\end{array}$ & $\begin{array}{c}2 \\
(25 \%)\end{array}$ & $\begin{array}{c}1 \\
(16 \%)\end{array}$ & $\begin{array}{c}1 \\
(33 \%)\end{array}$ & $\begin{array}{c}5 \\
(20 \%)\end{array}$ \\
\hline Encourage development & $\begin{array}{c}0 \\
(0 \%)\end{array}$ & $\begin{array}{c}2 \\
(25 \%)\end{array}$ & $\begin{array}{c}3 \\
(50 \%)\end{array}$ & $\begin{array}{c}0 \\
(0 \%)\end{array}$ & $\begin{array}{c}5 \\
(20 \%)\end{array}$ \\
\hline Bridge & $\begin{array}{c}0 \\
(0 \%)\end{array}$ & $\begin{array}{c}3 \\
(38 \%)\end{array}$ & $\begin{array}{c}0 \\
(0 \%)\end{array}$ & $\begin{array}{c}1 \\
(33 \%)\end{array}$ & $\begin{array}{c}4 \\
(16 \%)\end{array}$ \\
\hline Improve popular participation & $\begin{array}{c}0 \\
(0 \%)\end{array}$ & $\begin{array}{c}2 \\
(25 \%)\end{array}$ & $\begin{array}{c}1 \\
(16 \%)\end{array}$ & $\begin{array}{c}0 \\
(0 \%)\end{array}$ & $\begin{array}{c}3 \\
(12 \%)\end{array}$ \\
\hline Advocate & $\begin{array}{c}0 \\
(0 \%)\end{array}$ & $\begin{array}{c}1 \\
(13 \%)\end{array}$ & $\begin{array}{c}1 \\
(16 \%)\end{array}$ & $\begin{array}{c}0 \\
(0 \%)\end{array}$ & $\begin{array}{c}2 \\
(8 \%)\end{array}$ \\
\hline
\end{tabular}

\subsection{Normative Conceptualisations of Working Journalists}

Table 5 summarises what 29 Category 2 interviewees, journalists working at local and international media see as the main functions, skills and ethics of journalism. Responses here are to questions including: What are the most important roles of a journalist? What are the main values that a good journalist should have?

\footnotetext{
8 Overall number of interviewees in this category.

9 Percentage of Category 2 interviewees overall.
} 
Table 5. Normative conceptualisations of working journalists.

\begin{tabular}{cccc}
\hline & JI & JL & Overall \\
& $\mathbf{( 1 1 )}$ & $\mathbf{( 1 8 )}$ & $\mathbf{( 2 9 )}$ \\
\hline Inform & 8 & 16 & $\mathbf{2 4}$ \\
Affect change & $(73 \%)$ & $(89 \%)$ & $\mathbf{( 8 2 \% )}$ \\
Improve democracy & 8 & 13 & $\mathbf{2 1}$ \\
Bridge & $(73 \%)$ & $(72 \%)$ & $\mathbf{( 7 2 \% )}$ \\
Watchdog & 9 & 9 & $\mathbf{1 8}$ \\
& $(82 \%)$ & $(50 \%)$ & $\mathbf{( 6 2} \%)$ \\
Educate & 4 & 7 & $\mathbf{1 1}$ \\
& $(36 \%)$ & $(39 \%)$ & $\mathbf{( 3 7 \% )}$ \\
Improve human rights & 3 & 7 & $\mathbf{1 0}$ \\
& $(27 \%)$ & $(39 \%)$ & $\mathbf{( 3 4 \% )}$ \\
Attack government & 2 & 7 & $\mathbf{9}$ \\
Improve society & $(18 \%)$ & $(39 \%)$ & $\mathbf{( 3 1 \% )}$ \\
& 3 & 4 & $\mathbf{7}$ \\
& $(27 \%)$ & $(22 \%)$ & $\mathbf{( 2 4 \% )}$ \\
& 2 & 5 & $\mathbf{7}$ \\
& $(18 \%)$ & $(28 \%)$ & $\mathbf{( 2 4 \% )}$ \\
Exert political influence & 2 & 3 & $\mathbf{5}$ \\
& $(18 \%)$ & $(17 \%)$ & $\mathbf{( 1 7 \% )}$ \\
& 0 & 4 & $\mathbf{4}$ \\
Help development/promote Asian values & $(0 \%)$ & $(22 \%)$ & $\mathbf{( 1 3 \% )}$ \\
& 1 & 3 & $\mathbf{4}$ \\
& $(9 \%)$ & $(17 \%)$ & $\mathbf{( 1 3 \% )}$ \\
\hline
\end{tabular}

A number of thematic tendencies emerged from the dataset which related to the primary research questions as follows.

\subsection{Theme A. 'Developing Democracy' Seen as a Key Journalism Function}

Developing, improving and facilitating democracy was seen as a primary journalistic role among both sets of interviewees (Over half in both main categories). One donor described how almost all the money available to do training was from groups which believed facilitating a democratic political system was a central journalism function.

"They all felt free and fair and open media would help to bring about the democratic process. In some countries it's been more apparent than others." -DR

This emphasis is reflected by trainers, one of whom says of journalists they help to train.

"The job [of the press] is to bring society to a point where the democracy level will change." - TI

This thinking is echoed by a practitioner working with an international organization:

"I think it is very important [for journalism] to bring democracy. If [Cambodians] don't know about [democracy] it is easier to boss them." - JL

It can be argued that the norm of 'improving popular participation' is a less loaded and less political interpretation of the role the press can play in improving democratic preconditions. However, this is only mentioned by two interviewees in the 'facilitator' category, while no participants mention it.

\subsection{Theme B. 'Affect Change' Function Features More Strongly among Journalists Than Facilitators}

Seeing the role of the journalist as someone who actively seeks to affect change is a strong normative ideal among journalists interviewed (more than two thirds mention this), but is much less prominent among facilitators (Less than a third). There is significant deviation in this regard 
between Cambodian trainers, more than $60 \%$ of whom reference 'affect change' as a key role, versus international trainers (one in ten). This suggests a number of things, one of them being that programme participants tended to view journalism as an active, direct-action oriented practice. As one journalist working for an international outlet puts it:

"You don't just wait and see what happens and write about the public reaction. Sometimes you have to play a role to find something that will help the society." - JL

Another journalist working in a local outlet describes:

"I can change my country by becoming a journalist in a way that I cannot by being a teacher." —JL

Another equates journalists and politicians directly.

"In the future journalists have to know, not only how to write articles, they have to be themselves like a doctor ... cure the problem." - JL

The interview responses here point to a 'softer' conceptualisation among international trainers and donors about journalism as a vehicle for social and political change, than is the case with local trainers and programme participants. More specific 'issue oriented' and subtle variations of the norm such as "improve human rights", "improve society" and "improve the government" are much more common among trainers than among journalists.

\subsection{Theme C. Journalism Seen as Having an Explicitly Political Function}

Seeing journalism as an explicitly political activity is common among most of those that were interviewed, but there was a good deal of variation found within this as a concept. These range from more exploratory and interpretive orientations of the relationship between journalism and the political process to ones which are much more explicitly participatory. One local trainer puts it:

"Before you jump into politics, you (do) journalism first." — TL

Journalism is linked to an interest in politics, both in terms of putting forward political points of view and/or questioning dominant political viewpoints. 'Exerting political influence' is seen as a function of journalism by one fifth of all facilitators interviewed, (This included half of local trainers). This political conceptualisation tends to be articulated by facilitators in fairly neutral, or positivist terms, for example in terms of 'questioning authority' or 'improve the government' (a fifth of facilitators mention this while no participants do). Participants, on the other hand, tend more towards a polarised interpretation of this function, with more than a third of them seeing their role as journalists as being to 'attack the government' or 'to get involved in politics' (no facilitator mentioned this). This also relates to a far stronger incidence of 'inform' as a key journalistic function among programme facilitators, (it is the most mentioned journalism function in this category). As one local trainer puts it:

"[Journalists] give information to people so people can make their value judgement." - TL

While 'inform' also features highly as a key function among journalists, there are subtle counterpoints in terms of how 'inform' is interpreted, with $40 \%$ of local journalists saying a key journalistic function is to educate, for example:

"We must educate the audience, explain to them and make them understand." -JL

This interpretation exchanges a function, understood as to receive and communicate accurate, pertinent and unbiased information in a clear and unvarnished way to readerships, for a more top-down or one-way function with the journalist as an 'educator' passing on his knowledge and beliefs, along with particular political orientations either implicitly, or explicitly, to the reader. 


\subsection{Theme D. Divergence over the Importance of Neutrality, Objectivity and Independence}

These terms are gathered together into one value for the purposes of this study, even though there are crucial differences between them. 'Objectivity', as understood here, refers to aspiring to be as fair or non partisan as possible ${ }^{10}$ while striving to reach a version of truth, while 'neutrality' leans toward allowing for the expression of all perspectives while not expressing any preference in your writing. The 'neutrality' value is referenced strongly among international trainers interviewed (over one third), while no local trainers reference it. Among these trainers, this value veers a little more toward objectivity, but the difference is not very clear. One international trainer describes:

"[we teach them] not to take sides politically. The newsroom is a non-political area, even though some people have strong views." - TI

Another states that objectivity is important, but offers little explanation of what that is

"I think [journalists] can take on board and understand the need for ... objectivity and all of that.

It is common sense." - TI

Among participants then, this value tends to be expressed more in terms of neutrality, but much stronger among international journalists (over a quarter of those interviewed) than local.

Independence as a value is skewed differently among facilitators, with more than a quarter of local trainers and participants who work in local media mentioning it as a key value, compared to half that among international trainers and participants who work in international organisations. Amongst the local media participant category however, there is a marked tendency to equate 'independence' with being against the government or pro-opposition. As one describes:

"I don't want to write a story to support the government because such a story would be the opposite of my opinion." - JL

\subsection{Theme E. Basic Skills/Vocational Approach to Training Emphasised over a More Educational Approach}

Findings here suggest a de-emphasising of complexities of journalism as a practice among facilitators and participants. Practical or basic journalism skills are seen as being most important by most interviewees in all categories, with little mention of the need for more a grounding in higher level theory and education for practicing journalists. One donor expressed concerns about blasé attitudes toward journalism training among facilitators. Recalling how a senior figure within an international journalism training organisation had told her that three days was sufficient to impart basic journalism skills, she recalls:

"I thought-what kind of training did they get? What can you learn in three days, frankly, that can be any good?" -DR

This belief in practical skills above all else links strongly to a belief that short-term vocational or 'on-the-job' training is superior to a more education-oriented approach. As one journalist put it:

"IIn college] you only learned the theory. We did not know the practice. The job teaches" -JL

A belief that learning journalism is a simple, top-down formula also manifests in the view that skills and curricula should originate from the west. This view is articulated by more than half of both categories of interviewees (this features more strongly in interviewee sub-categories of international trainers and programme participants who went onto work with international organisations).

10 My understanding of the term here is also influenced by Soffer (2009)'s definition of objectivity in journalism as mediating a factual, single public reality on the basic of impartial observation and gathering of facts. 


\section{Analysis and Discussion of Data}

Three main tendencies can be seen within interview responses, which have implications in terms of the research questions posed.

Firstly, responses here provide evidence that the democratic normative ideal was a significant influence in the conceptualisation of journalism propounded by media aid organisations in Cambodian in the early 1990s. While an initial examination of responses shows that belief in this as a key journalistic ideal is shared by current practitioners who would have attended these programmes, more in-depth analysis reveals other currents which suggest that belief in the democratic norm among practitioners in particular may not be deeply held.

While there is some evidence of the presence of all three of Berger (2000) variants of the democratic norm in facilitator and participant responses, it is the liberal variant which can be seen to be the more dominant conceptualisation. This variant sees journalism as an active, autonomous force (even where existing within a polarised media), safeguarding citizens' rights and holding the powerful accountable, with high levels of belief in the watchdog norm as a key element needed for democratic openness and transparency.

However, this study also finds evidence of other more problematic tendencies which Berger saw as being connected to the liberal democratic variant (particularly in a developing world environment). Examples include the watchdog role being interpreted as a mandate to unseat undemocratic governments, and a more explicitly political orientation among journalists. Analysis of interviews highlights that facilitators emphasised the watchdog function of journalism as a key tenet underpinning the democratic norm. Responses from programme participants, however, tend towards a more explicitly politicised interpretations of the relationship between journalism and the democratic process. These manifested itself in the high incidence among participants of ideas like 'attack the government', and 'affect change' as key journalistic functions.

A second observation here is that the short-term vocational orientation of journalism programmes in Cambodia may have contributed to the kind of interpretations of the journalism democratic norm among participants as highlighted above. Previous studies about vocationally oriented journalism training in western settings highlight how this approach lessens journalism's public service function (Carey 2000) or oversimplifies intellectual complexities (Parisi 1994). This would support the view that a vocational, 'broad brushstroke' approach to explaining the relationship between journalism and democracy during training in Cambodia might have contributed to participants' interpretations of the democratic norm diverging from that of facilitators. Thus, programme facilitators' more neutral democratisation facilitation role conceptualisations like 'improving popular participation' can be replaced by participants' more explicitly political definitions such as 'attacking the government' as a key journalistic role. This tendency would likely have been added to given the politically polarised environment in which they had to operate in as journalists after training.

Weaker conceptualisations of the democratic normative ideal among journalists have significant implications in environments such as that of Cambodia. This research acknowledges the literature on culturally specific democratic inhibitors in the Asian region such as the congruence of Confucianism (Eckstein 1998), the depth of the cultural foundations for Asian Values journalism ${ }^{11}$ and others, but it tends to agree with more recent studies that argue that many of these 'democratisation-impairing' cultural specificities may not have the inhibitory effect than had been thought (Tomaselli 2003; Xu 2005). However, doubts over the degree and extent to which these kind of factors inhibit democratisation does not mean these factors do not have any effect.

11 'Asian values' journalism is a type of development journalism, in which an engagement with ideas like democracy or freedom of speech is subjugated to the interests of economic expansion and development (Edeani 1993; Wimmer and Wolf 2005). The likes of Okigbo (1985) and Blake (1997) have shown how a press with these characteristics can be manipulated into becoming a government mouthpiece. 
A press culture in which journalists manifest limited understandings of key journalistic norms could certainly feed into a scenario whereby these democracy-inhibiting factors do have an impact and gain popular credibility. A generalised belief in democracy among press practitioners is not the same as actually contributing to an environment in which democracy can come into existence. Conceptualisations of journalistic roles and norms which are more facilitative in character, for example which reference the creation of a public sphere, or which enhance popular participation, are notable by their absence in the responses, especially among practitioners.

Instead of driving the creation of a healthy and vibrant public sphere in which reasoned debate and argument takes place, journalists lacking in belief in and understanding of the theoretical underpinnings of journalism's relationship with its political environment can be vulnerable to becoming agents of and contributors toward a politically polarised environment, in which ideas about 'cultural suitability' of democracy and Asian values journalism gain more traction.

A third observation emanating from interviews outlined here is that mixing advocacy with journalism training may have contributed to a press culture which added to levels of political parallelism in Cambodia. The high incidence of belief in normative ideals such as 'affect change', 'exert political influence' and 'advocate' among programme facilitators in Cambodia suggests that many journalism programmes in Cambodia were founded on belief systems similar to those ascribed to Schudson (2002) advocacy press model. Here, the press tends towards a partisan role, and is less focused on informing as they are in exhorting participation or adherence to a particular perspective or viewpoint. This advocacy tendency is a feature of a more interpretive, commentary-oriented or politically polarised style of journalism, which has been linked to a type of political parallelism (as described by Hallin and Mancini 2004) whereby media organisations reflect political tendencies.

The type of training which predominated in Cambodia may have emphasised advocacy at the expense of a more journalism focus (Several programme facilitators expressed concern about this specifically). A subsequent tendency of journalists to see their role in terms of advocating for particular causes is reflected in low levels of belief in values such as 'neutrality' among journalists, combined with high levels of belief in partisan-oriented journalistic functions such as 'affect change' and 'exert political influence', among others.

There are indications also that the depth of suspicion among officialdom of the press is in part due to the perception that the nascent press sector was advocating for political and social agendas on behalf of foreign interests. A USAID (1999) report acknowledges this in terms of the media in general, when it said that "democratic transitions may not be strengthened through the creation of a media, which, while free from its own government control, espouses views of foreign governments and reflects their interests (USAID 1999, p. 9). It is important to note here very strongly that the relatively small sample size here as well as the vast range of other factors influencing journalists from the time they participated in programmes to where they were interviewed here, prohibits any claims of a direct causal relationship between training received and the media culture that developed in Cambodia. However, some of the tendencies highlighted here do suggest that partisan conceptualisations of journalistic roles at such a critical moment in the development in a press culture as is the case in Cambodia in 1993 onwards, may not have helped in the cultivation of a media climate in which the free and open debate which serves genuine political pluralism and participatory democracy can flourish.

\section{Conclusions}

To briefly summarise, this study highlights that journalism training programmes carried out in Cambodia in the early 1990s manifested the democratic ideal of journalism as a central tenet. This is parallelled by normative conceptualisations among current practitioners who also emphasise the democratic ideal as a core norm. However, practitioners' descriptions exhibit variations of the ideal which are more explicitly and actively political in character. Training which was vocational, short-term, advocacy oriented and lacking a grounding in local specificities may have contributed to this tendency. 
This study is somewhat limited in its scope and a number of useful further avenues for research are suggested going forward: Firstly a study of the democratic ideal conceptualisations of journalists who have only been exposed to a more educational approach to journalism training versus a group of students who only participated in vocational training would interrogate further whether more educational orientated journalism programmes increase understanding of the nuances of certain journalism ideals.

Findings here also have implications for organising journalism programmes in environments similar to that presented by Cambodia in the early 1990s—specifically post conflict, developing world environments which can be termed transitional democracies. A comparative analysis between findings here and those from projects in similar countries would reveal more about the effect of training emphases in particular environments. Examples could include culturally similar countries in the same region, such as Burma or Laos. Comparative studies might also usefully be done in countries such as Afghanistan, which is regarded as transitional democracy with issues similar to those faced by Cambodia in the early 1990s, and also has a high degree of emphasis on media development projects as part of rebuilding efforts there.

Findings here suggest the following steps going forward in environments similar to that faced by Cambodia in the 1990s. Firstly, individual journalists must be educated to a degree which goes beyond the learning of basic journalism practice, in order for them to better achieve normative ideals, such as the democratic one. One means of achieving this may lie in the examination of approaches to journalism programmes that incorporate a more theoretical approach earlier on, while also retaining the vitally important emphasis on vocational and practical skills. The highly theoretical approach that predominated in Eastern Europe under socialist governments (Aumente et al. 1999) might be worth reexamining in this regard. While this model was rejected to a large degree due to it being compromised politically, it should be examined again for useful elements that might be considered in future approaches to journalism programmes in a developing world environment, especially ones similar to Cambodia, where journalists were being trained in a society emerging from a more controlled, authoritarian regime.

Tendencies highlighted in this study also contribute to the case against a "one-size fits all" model of free press encouragement in a developing democracy environment such as that of Cambodia in the early 1990s. Instead, it suggests that poorly theorised and implemented approaches to journalism training which included an over-emphasis on the democratic norm during training, without a wider theoretical contextualising, may not have effectively supported the overall aim of democratic consolidation that facilitators hoped for.

While challenging assumptions about the strength of the link between the free press and democratisation in a non-western environment, this research does not suggest that the democratic norm of journalism is undesirable in a developing world context. In particular, the social democratic variant of the norm (as described in the earlier 'Democracy and Journalism section) would appear to retain usefulness, but only if overly collaborative tendencies which can lead to the press being instrumentalised are avoided.

Finally, any new paradigm of approaches to journalism education in the Global South must establish a more nuanced understanding of what the relationship between democratic participatory practices and the press should mean in a broader societal sense. This requires incorporating enhanced focus in training upon connections between the duties of news producers and rights of those who are consuming the news, are affected by or are the subject of news.

Funding: This research received no external funding.

Conflicts of Interest: The author declares no conflict of interest. 


\section{References}

Anderson, Christopher W. 2014. The sociology of the professions and the problem of journalism education. Radical Teacher 99: 62-68. [CrossRef]

Appadurai, A. 1996. Modernity al Large: Cultural Dimensions of Globalization. Minnesota: U of Minnesota Press, Vol. 1.

Aumente, Jerome, Peter Gross, Ray Hiebert, Owen Johnson, and Dean Mills. 1999. Eastern European Journalism: Before, During and After Communism. New York: Hampton Press.

Banda, Fackson. 2007. An appraisal of the applicability of development journalism in the context of public service broadcasting (PSB). Communication 33: 154-70.

Barrera, Carlos. 2012. Transatlantic Views on Journalism Education Before and after World War II: Two Separate worlds? Journalism Studies 13: 534-49. [CrossRef]

Beiser, Elana. 2018. Hundreds of journalists jailed globally becomes the new normal. Committee to Protect Journalists. Available online: https://cpj.org/reports/2018/12/journalists-jailed-imprisoned-turkey-china-egypt-saudiarabia/ (accessed on 12 November 2020).

Bennett, W. Lance. 1998. The media and democratic development: The social basis of political communication. Communicating Democracy: The Media and Political Transitions 195-207.

Berger, Guy. 2000. Grave new world? Democratic journalism enters the global twenty-first century. Journalism Studies 1: 81-99. [CrossRef]

Biernacki, Patrick, and Dan Waldorf. 1981. Snowball sampling: Problems and techniques of chain referral sampling. Sociological Methods E Research 10: 141-63.

Blake, Cecil. 1997. Democratisation: The dominant imperative for national communication policies in Africa in the 21st Century. Gazette 59: 253-69. [CrossRef]

Braun, Virginia, and Victoria Clarke. 2006. Using thematic analysis in psychology. Qualitative Research in Psychology 3: 77-101. [CrossRef]

Bumille, E. 2012. In Cambodia, Panetta Reaffirms Ties with Authoritarian Government. New York Times, November 16.

Cammaerts, Bart, Brooks DeCillia, and João Carlos Magalhães. 2017. Journalistic transgressions in the representation of Jeremy Corbyn: From watchdog to attackdog. Journalism 21: 191-208. [CrossRef]

Carey, James W. 2000. Some Personal Notes on US Journalism Education. Journalism, Theory, Practice and Criticism 11: 9-12. [CrossRef]

Christians, Clifford G. 2009. Normative Theories of the Media. Champaign: University of Illinois Press.

Clarke, Judith. 1995. Phoenix from the ashes: The influence of the past on Cambodia's resurgent free media. Gazette 55: 93-111. [CrossRef]

Cortadi, J., P. Weiss Fagan, and M.A. Garreton. 1992. Fear at the Edge: State Terror and Resistance in Latin America. Berkley: University of California Press.

Datta-Ray, Sunanda K. 2006. Asia must evolve its own journalistic idiom. Issues and Challenges in Asian Journalism 44-64.

Denzin, N. 1997. Interpretive Ethnography: Critical Pedagogy and the Politics of Culture. Thousand Oaks: Sage.

Deuze, Mark. 2005. What Is Journalism? Professional Identity and Ideology of Journalists Reconsidered. London: Sage.

Dissanayake, W. 1988. The Need for Asian Approaches to Communication. Edited by Dissanayake, W. Communication Theory: The Asian perspective. Singapore: Asian Mass Communication Research and Information Center, pp. 1-19.

Donohue, George A., Phillip J. Tichenor, and Clarice N. Olien. 1995. A Guard Dog Perspective on the Role of Media. Journal of Communication 45: 115-32. [CrossRef]

Dube, Bevelyn. 2016. Rethinking journalism education in African journalism institutions: Perspectives of Southern African journalism scholars on the Africanisation of journalism curricula. AFFRIKA Journal of Politics, Economics and Society 6: 13-45.

Eckstein, Harry. 1998. Congruence Theory Explained. In Can Democracy Take Root in Post-Soviet Russia? Explorations in State-Society Relations. Edited by Reisinger William. Lanham: Rowman \& Littlefield.

Edeani, David O. 1993. Role of development journalism in Nigeria's development. Gazette 52: 123-43. [CrossRef]

El Issawi, Fatima, and Bart Cammaerts. 2016. Shifting journalistic roles in democratic transitions: Lessons from Egypt. Journalism 17: 549-66. [CrossRef] 
Entman, Robert M. 2010. Media framing biases and political power: Explaining slant in news of Campaign 2008. Journalism 11: 389-408. [CrossRef]

Foley, Michael. 2006. Promoting values-As West meets East. International Journal of Communication Ethics 3: 21-25.

Foley, Michael. 2010. The Press and Democracy Building: Journalism Education and Training in Eastern and South-Eastern Europe during Transition. Master's dissertation, Technological University Dublin, Dublin, Ireland.

Freedom House. 2020. Annual Report. Available online: https://freedomhouse.org/country/cambodia (accessed on 25 June 2020).

Gardeström, Elin. 2017. Losing Control: The emergence of journalism education as an interplay of forces. Journalism Studies 18: 511-24. [CrossRef]

Hackett, Robert A. 2017. Democracy, climate crisis and journalism: Normative touchstones. In Journalism and Climate Crisis. London: Routledge, pp. 20-48.

Hallin, Daniel C., and Paolo Mancini. 2004. Comparing Media Systems: Three Models of Media and Politics. Cambridge: Cambridge University Press.

Hamada, Basyouni Ibrahim. 2016. Towards a global journalism ethics model: An Islamic perspective. The Journal of International Communication 22: 188-208. [CrossRef]

Hanitzsch, Thomas, and Tim P. Vos. 2018. Journalism beyond democracy: A new look into journalistic roles in political and everyday life. Journalism 19: 146-64. [CrossRef]

Hanitzsch, T., F. Hanusch, C. Mellado, M. Anikina, R. Berganza, I. Cangoz, M. Coman, B. Hamada, M. Elena Hernández, C.D. Karadjov, and et al. 2011. Mapping journalism cultures across nations: A comparative study of 18 countries. Journalism Studies 12: 273-93. [CrossRef]

Harvey, D. 2005. A Brief History of Neoliberalism. Oxford: Oxford University Press.

Herman, E., and R. McChesney. 1997. The Global Media: The New Missionaries of Corporate Capitalism. New York: Continuum.

Hoepfl, Marie C. 1997. Choosing qualitative research: A primer for technology education researchers. Journal of Technology Education 9: 47-63. [CrossRef]

Jallov, Birgitte. 2005. Journalism as a Tool for the Formation of a Free, Informed and Participatory Democratic Development. In Swedish Support to a Palestinian Journalist Training Project on the West Bank and Gaza for the Period 1996-2005. Stockholm: SIDA.

Josephi, Beate. 2005. Journalism in the global age: Between normative and empirical. Gazette 67: 575-90. [CrossRef]

Josephi, Beate Ursula. 2010. Journalism Education in Countries with Limited Media Freedom. New York: Peter Lang. Josephi, Beate. 2013. How much democracy does journalism need? Journalism 14: 474-89. [CrossRef]

Josephi, Beate. 2017. Journalists for a Young Democracy. Journalism Studies 18: 495-510. [CrossRef]

Kalyango, Yusuf, Jr., Folker Hanusch, Jyotika Ramaprasad, Terje Skjerdal, Mohd Safar Hasim, Nurhaya Muchtar, Mohammad Sahid Ullah, Levi Zeleza Manda, and Sarah Bomkapre Kamara. 2017. Journalists' development journalism role perceptions: Select countries in Southeast Asia, South Asia, and sub-Saharan Africa. Journalism Studies 18: 576-94. [CrossRef]

Lamb, K. 2018. Cambodia 'Fake News' Crackdown Prompts Fears over Press Freedom. The Guardian. Available online: https://www.theguardian.com/world/2018/jul/06/cambodia-fake-news-crackdown-prompts-fearsover-press-freedom (accessed on 13 November 2020).

Lo, V.H., J.M. Chan, and Z. Pan. 2005. Ethical attitudes and perceived practice: A comparative study of journalists in China, Hong Kong and Taiwan. Asian Journal of Communication 15: 154-72. [CrossRef]

Lugo-Ocando, Jairo. 2018. A mouthpiece for truth: Foreign aid for media development and the making of journalism in the global south. Brazilian Journalism Research 14: 412-31. [CrossRef]

Mahler, Anne Garland. 2018. From the Tricontinental to the Global South: Race, Radicalism, and Transnational Solidarity. Duke: Duke University Press.

Matthews, Julian, and Kelechi Onyemaobi. 2020. Precarious Professionalism: Journalism and the Fragility of Professional Practice in the Global South. Journalism Studies 21: 1836-51. [CrossRef]

McNair, Brian. 2009. Journalism in the 21st century-Evolution, not extinction. Journalism 10: 347-49. [CrossRef]

Meyers, C. 2016. Universals without absolutes: A theory of media ethics. Journal of Media Ethics 31: 198-214. [CrossRef] 
Murthy, C.S.H.N. 2010. Education in Mass Communication-Challenges and Strategies: A Case Study of Indian Scenario. The Romanian Journal of Journalism \& Communication 1: 5-16.

Nielsen, Rasmus Kleis. 2017. The one thing journalism just might do for democracy: Counterfactual idealism, liberal optimism, democratic realism. Journalism Studies 18: 1251-62. [CrossRef]

Okigbo, Charles. 1985. Media use by foreign students. Journalism Quarterly 62: 901-4. [CrossRef]

Papoutsaki, Evangelia. 2007. Decolonising journalism curricula: A research and 'develop-ment' perspective. Media Asia 34: 71-87. [CrossRef]

Parisi, Peter. 1994. Critical Studies, The Liberal Arts and Journalism Education. Journalism Educator 464: 4-13. [CrossRef]

Plaisance, P.L., E.A. Skewes, and T. Hanitzsch. 2012. Ethical orientations of journalists around the globe: Implications from a cross-national survey. Communication Research 39: 641-61. [CrossRef]

Prado, Paola. 2017. Mapping citizen journalism and the promise of digital inclusion: A perspective from the Global South. Global Media and Communication 13: 87-104. [CrossRef]

Pye, L., and M. Pye. 1985. Asian Power and Politics. Cambridge: Belknap Press.

Quinn, Fergal. 2018. Failing to Prepare? Journalism Ethics Education in the Developing World: The Case of Cambodia. Journal of Media Ethics 33: 50-65.

Rao, Shakuntala, and Herman Wasserman. 2007. Global media ethics revisited: A postcolonial critique. Global Media and Communication 3: 29-50. [CrossRef]

Reporters San Frontiers. 2019. Annual Report. Available online: https://rsf.org/en/cambodia (accessed on 5 October 2020).

Schudson, Michael. 1998. The Good Citizen. New York: Free Press.

Schudson, Michael. 2002. The Sociology of News. New York: Norton.

Soffer, Oren. 2009. The competing ideals of objectivity and dialogue in American journalism. Journalism 10: 473-91. [CrossRef]

Tomaselli, Keyan G. 2003. 'Our Culture' vs. 'Foreign Culture' An Essay on Ontological and Professional Issues in African Journalism. Gazette 65: 427-41. [CrossRef]

Tsukamoto, S. 2006. Social responsibility theory and the study of journalism ethics in Japan. Journal of Mass Media Ethics 21: 55-69. [CrossRef]

UNESCO. 2013. Teaching Journalism in Developing Countries and Emerging Democracies: The Case of UNESCO's Model Curricula. UNESCO. Available online: bit.ly/1kYHRPX (accessed on 3 September 2018).

United Nations Transitional Authority in Cambodia (UNTAC). 1991. Media Guidelines for Cambodia, Drafted by the Information and Education Division of the United Nations Transitional Authority in Cambodia. Available online: http://www.aceproject.org/ero-en/topics/media-and-elections/mex08.pdf (accessed on 20 October 2020).

US Agency for International Development (USAID). 1999. The Role of Media in Democracy, a Strategic Approach. Available online: http://www.usaid.gov/sites/default/files/documents/2496/200sbc.pdf (accessed on 20 October 2020).

Vasilendiuc, Natalia, and Rodica Melinda Sutu. 2020. Journalism Graduates Versus Media Employers' Views on Profession and Skills. Findings from a Nine-Year Longitudinal Study. Journalism Practice 1-18.

Ward, Stephen JA. 2008. Global Journalism Ethics: Widening the Conceptual Base. Global Media Journal 1: 137.

Wasserman, H., and A.S. De Beer. 2004. Covering HIV/AIDS: Towards a heuristic comparison between communitarian and utilitarian ethics.

Wimmer, Jeffrey, and Susanne Wolf. 2005. Development Journalism out of Date? An Analysis of Its Significance in Journalism Education at African Universities. Munich: Munich Contributions to Communication.

Xu, Xiaoge. 2005. Demystifying Asian Values in Journalism. Singapore: Marshall Cavendish Academic.

Publisher's Note: MDPI stays neutral with regard to jurisdictional claims in published maps and institutional affiliations.

(C) 2020 by the author. Licensee MDPI, Basel, Switzerland. This article is an open access article distributed under the terms and conditions of the Creative Commons Attribution (CC BY) license (http://creativecommons.org/licenses/by/4.0/). 